UDC 930.272

Submitted: 20.03.2016

LBC 63.3(2)43

Accepted: 30.08 .2016

\title{
DEACON OLESHKA PAVLOV AND BOOKWRITING IN KIRILLO-BELOZERSKY MONASTERY IN THE FIRST HALF OF THE 15TH CENTURY
}

\author{
Mikhail A. Shibaev \\ National Library of Russia, Saint Petersburg, Russian Federation
}

\begin{abstract}
The article is devoted to one of the writers who created the books for Kirillo-Belozersky Monastery. Deacon Oleshka Pavlov was the teacher of grammar and the booklore mentor of Martinian of Belozersk who later became reverend as well as some other monks. The analysis of the acts and the hagiographical texts allows to reconstruct the biography of the scriber and to come to the conclusion, that the deacon of the parish temple Oleshka had not got the direct connection with Kirillo-Belozersky Monastery, he lived outside, in Feodosjin town with his father, priest Pavel. The article includes the autographs of Oleshka and determines the chronological borders of the books, which were rewritten by him: from the 1410s to the second half of 1440s. In the article the earlier works of the predecessors - R. Romanchuk, E.E. Shevchenko, I. Ševčenco, etc. were critically analyzed. Besides, the books with the inscriptions of Oleshka, four books, which were written with participation of deacon, were identified. Oleshka had half-uncial handwriting of not very good quality and, clearly, he wasn't a professional calligrapher. Moreover, some manuscripts were commissioned to him, and not only by Kirillo-Belozersky monastery. Most of the books which were written by Oleshka were not noted in the monasterial register of the books by the middle of the 1480s.

The codicological observations on the one of the manuscripts allowed to come to the conclusion that the deacon was able to contact with the monasterial direction only sporadically, he received the written orders. So, it is not likely, that Oleshka was the director of the junior school for the young inhabitants of Kirillo-Belozersky monastery. In the first half of the 15th century, Kirillo-Belozersky monastery was forced to use the local clerics as well as brothers for book writing. The research on Oleshka's biography allowed to come to the conclusion, that the organization of book writing in Kirillo-Belozersky monastery was of comparatively low level in the first half of the 15th century.

Key words: Kirillo-Belozersky Monastery, Reverend Kirill Belozersky, Reverend Martinian Belozersky, Oleshka Pavlov, hegumen Trifon, Old Russian literature, codicology.
\end{abstract}

\section{ДЬЯК ОЛЕШКА ПАВЛОВ И КНИГОПИСНОЕ ДЕЛО В КИРИЛЛО-БЕЛОЗЕРСКОМ МОНАСТЫРЕ В ПЕРВОЙ ПОЛОВИНЕ ХУ ВЕКА}

\author{
Михаил Алексеевич Шибаев \\ Российская национальная библиотека, г. Санкт-Петербург, Российская Федерация
}

\footnotetext{
Аннотация. Статья посвящена одному из писцов, создававшему книги для Кирилло-Белозерского монастыря. Дьяк Олешка Павлов был учителем грамотности и наставником в книжном деле ставшего впоследствии преподобным Мартиниана Белозерского и некоторых других монахов. Анализ актовых и агиографических источников позволяет реконструировать биографию книжника и прийти к выводу о том, что дьякон приходской церкви Олешка не имел прямого отношения к Белозерскому монастырю, проживал вне его стен в Федосьином 巴ै городке вместе со своим отцом священником Павлом. В статье атрибутируются автографы Олешки и опредео ляются хронологические рамки переписанных им книг - с 1410-х гг. до второй половины 40-х гг. XV века. Рассмотрение биографии Олешки позволяет сделать вывод о достаточно скромной организации книгописного () дела в обители в первой половине XV века.
} 
Ключевые слова: Кирилло-Белозерский монастырь, преподобный Кирилл Белозерский, преподобный Мартиниан Белозерский, Олешка Павлов, игумен Трифон, древнерусская книжность, кодикология.

На рубеже XIV-XV вв. в пределах Cеверо-Восточной Руси складываются несколько крупных книжных собраний, в том числе и библиотека Кирилло-Белозерского монастыря. Основатель обители преподобный Кирилл заложил основы общежительных порядков и заботился о пополнении своей монастырской библиотеки. Однако механизм формирования книжного собрания еще недостаточно изучен, поэтому попытка реконструкции биографии одного из первых книжников монастыря может пролить свет на этот вопрос. Жизненный путь исследуемого нами писца может быть реконструирован по трем основным видам источников: агиографическим текстам, записям и автографам в книгах, а также актовому материалу, относящемуся к Кирилло-Белозерскому монастырю.

В Житии Мартиана Белозерского, составленном в XVI в., есть эпизод, когда святой Кирилл попросил обучить грамоте юношу Михаила Стомонахова (будущего преподобного) Олешу Палкова (или Павлова), мирского (в других списках - монастырского) дьяка, живущего близ обители, прежде чем постричь в монахи. При этом в Житии подчеркивается, что Олешка занимался обучением грамотности и писанием книг [5, с. 216]. Наблюдения над списками с текстом Жития Мартиниана позволили Е.Э. Шевченко, кажется, окончательно снять вопрос о разночтении в статусе Олешки. Исследовательница предположила, что чтение «мирской» более древнее и первоначальное, а другое возникло позднее в ходе описки писца [5, с. 133-134].

Данные агиографического источника можно сопоставить с рукописями, к составлению и переписке которых имел отношение Олешка. В работе американского исследователя Р. Романчука во многом уже суммированы наблюдения предыдущей историографии и приведены выходные записи рукописей, атрибутируемых Олешке Павлову (Палкину) [6, с. 72-93]. Мы со своей стороны можем расширить число рукописей Олешки и приводим их в хронологической последовательности.

Первая по хронологии рукопись, где встречается манера его письма - это рукопись под названием Маргарит (ОР РНБ, Кирилло-Белозерское собр., № 116/241). Книга датируется 1410-1420 гг., а Олешка выступает здесь как простой писец. Вклад Олешки в создание рукописи был достаточно скромным, никаких писцовых записей о своем участии он не оставил. Манерой Олешки переписано только «Слово на Рождество Христово о пришествии волхвов» на л. 265-275 об. данной рукописи. Кодекс происходит из монастырской библиотеки и зафиксирован в монастырском каталоге книг середины 80-х гг. XV в. [11, с. 37].

Второй по древности рукописью, в переписке которой участвовал Олешка, является список Диоптры Филиппа Пустынника, датируемый 1426 г. (ОР ГИМ, собр. Уварова, № 369-4ㅇ‥ Рукопись-конволют состоит из нескольких разновременных блоков, механически собранных в один переплет. Помимо Диоптры, переписанной Олешкой, сборник содержит Слова Иоанна Солунского, Иоанна Златоуста, Василия Кесарийского, выписки из Пролога и др. Несмотря на то что рукопись сильно пострадала при многочисленных поновлениях и реставрациях и часть текста, переписанная манерой Олешки, утрачена, тем не менее сохранились фрагменты, которые надежно атрибутируются Олешке: л. 113 об., 18-48 об., 51-54 об., 58-60 об., 6363 об., 65-80 об., 82-87 об., 90-95 об., 97242. Однако самое главное, что на л. 242 находится выходная запись, где писец называет себя «последнем в грешницех именем Олешка». Важно отметить, что рукопись не атрибутируется библиотеке Кирилло-Белозерского монастыря.

K 20-м годам XV в. относится и часть сборника-конволюта юридического характеpa, где также присутствует автограф Олешки (ОР ГИМ, собр. Музейское, № 1009). В данной рукописи Олешка на л. 1-177 об. переписал начальную и самую древнюю часть книги в нынешнем ее виде, содержащую сборник учительного содержания, озаглавленный «Книга Богоносивых отец...». В состав этой части кодекса входят церковные Уставы Ярослава и Владимира, антилатинские сочинения, древнейший вариант южнославянского Пись- 
мовника. Частично тексты из этого сборника были изданы Я.Н. Щаповым [12, с. 14-16, 9193], а также в «Русском феодальном архиве» А.А. Туриловым и А.И. Плигузовым [8, c. 563-566]. Рукопись поступила в ГИМ из Костромского Ипатьевского монастыря. К сожалению, никаких выходных данных писец не оставил и происхождение рукописи остается неясным.

Нам не удалось пока обнаружить следы писцовой деятельности Олешки в 1430-е годы. Возможно, это связано с серьезным кризисом в монастыре после смерти в 1427 г. его первого игумена и основателя Кирилла и последующим моровым поветрием, унесшим жизни большей части монахов. Возобновление активной переписки книг, вероятно, началось уже при игумене Трифоне. В 1441 г. Олешка выполнил часть сборника святоотеческих трудов, основу которого составляют сочинения Кирилла Иерусалимского (ОР РНБ, Софийское собр., № 1248). Рукопись поступила в библиотеку Кирилло-Белозерского монастыря уже в XV в. и фиксируется в описи XV в. [11, c. 40]. В данной рукописи Олешка переписал на л. 2-328 об. сочинения Кирилла Иерусалимского, Никодимово Евангелие, Жития Константина и Елены, Иоанна Дамаскина. На л. 328 об. помещена выходная запись о создании рукописи «...грехослужимою десницею именем Олешка». Эта же рукопись содержит запись на верхнем поле на л. 263 об. (срезанные при переплетении буквы восстанавливаются в круглых скобках - М. Ш.): «(И)оаново Дамаскыново житие Б(ог)а ра(ди) нап(иш)и, г(осподи)не Александро». Запись сделана другой рукой и не похожа на манеру Олешки. Р. Романчук, прокомментировавший эту запись, совершенно справедливо предположил, что неизвестный заказчик обращается к писцу, то есть полное имя Олешки - Александр [6, с. 88-89]. И действительно, далее на л. 298328 об. в кодексе помещено Житие Иоанна Дамаскина, переписанное Олешкой. В связи с этим можно сделать несколько наблюдений, проливающих свет на принципы работы Олешки над рукописями. Между Житием Дамаскина и предшествующим ему Житием Константина и Елены присутствует явный кодикологический шов. Последняя 39-я тетрадь кодекса с Житием Константина содержит только два листа (л. 296-297), а остальные листы отрезаны, поскольку там не было текста. Следующие тетради с Житием Иоанна Дамаскина выполнены на бумаге, более в кодексе не встречающейся. Если бы Олешка получил задание по переписыванию Дамаскина еще во время создания предыдущего произведения, то он бы скорее не стал удалять лишние листы и продолжил переписывать следующий текст, то есть сначала Олешка предоставил заказчику только часть работы до нынешнего л. 297 и не планировал переписывать что-либо далее. Мы полагаем, что если заказчиком рукописи был сам игумен Трифон, то в случае постоянного контакта с ним книжник бы просто получил устное распоряжение, не требующее письменной фиксации. Олешка, скорее всего, мог лишь спорадически контактировать с заказчиком, получая от него письменные распоряжения.

Следующим по времени кодексом, к составлению и переписыванию которого имел отношение Олешка, является рукопись, датируемая 1446 г. (ОР РНБ, Кирилло-Белозерское собр., № 10/1087). Олешка лично переписал большую часть книги на л. 1-282, где помещены «Писание Иоанна Дамаскина о осьми частях слова», «Святого Максима изложение о вере вкратце», «Поучение избрано Григория Богослова от божественных его словес», «Златая Цепь» и ряд других произведений. На л. 282 им выполнена выходная запись, из которой следует, что рукопись была закончена в 1446 г.: «...грехослужимою десницею и последняго в грешницех именем Олешка». Эта рукопись содержит также очень важную кодикологическую информацию, на которую обратил внимание Р. Романчук [13, p. 151153]. При создании кодекса Олешка совместно работал вместе с другим писцом, который, по всей видимости, был его учеником, оставившим запись на л. 291 на полях вдоль текста: «Господи! Помози рабу своему Илариону, рука бы ему крепка писати, а ум бы ему цел и разум на всякое дело благое». Вероятно, рукопись не сразу попала в монастырскую библиотеку, поскольку не отмечена в монастырской описи середины 80-х гг. XV в.

Автограф Олешки зафиксирован нами также в житийном сборнике 40-х гг. XV в. (OP РНБ, собр. М. П. Погодина, № 796). Сборник 
содержит в своем составе Жития Саввы Освященного, Иоанна Кущника, Симеона Юродивого и Иоанна Пустынножителя, Феодоры Александрийской, Ефросиньи Александрийской, Марии Египетской, Февронии, Анастасии Римлянки, Марка Афинского, Андроника, Вопросы Василия Великого и ответы Григория Богослова, несколько Слов Иоанна Златоуста, Ефрема Сирина, Нифонта, Кирилла Туровского, Григория Богослова, а также большое количество монашеских поучений и слов. Содержание сборника подробно описано в 3-м выпуске Описания М.П. Погодина [7, с. 171177]. Перу Олешки принадлежит почти весь сборник, насчитывающий 373 л., за исключением небольших вкраплений на л. 180 об. (с 8-й строки снизу) - 181, 182-189, 308316 об., 365-373. Отметим, что другие манеры, которыми выполнен сборник, во многом сближаются с манерой самого Олешки. Возможно, это были его ученики или даже родственники, сыновья. Кодекс не находился в библиотеке Кирилло-Белозерского монастыря. Рукопись переписана Олешкой весьма беглым и достаточно неряшливым полууставом, что подразумевает скорее частный, а не заказной ее характер. Последняя книга заставляет задуматься о интересе Олешки к монашеской жизни, когда на склоне лет он вознамерился постричься в монахи. Но в таком случае он должен был получить новое имя и едва ли следует его искать в монастырском синодике под именем Александр, как полагает Р. Романчук [6, с. 82].

Особый случай представляет запись рукописи, содержащей Шестнадцать слов Григория Богослова (ОР РНБ, Погодинское собр., № 989). Рукопись датируется 1479 г. и содержит весьма пространную выходную запись на л. 340-340 об., где упомянут «ипактит Олешко, пореклом именуемыи Палкин». Запись привлекла внимание не только отечественных, но и зарубежных исследователей. Так, И. Шевченко предположил, что «ипактит» должен трактоваться как «монах» [14, р. 258-259]. Однако Р. Романчук, очередной раз опубликовавший запись со своими комментариями, отметил, что это является искажением древнеславянского слова [6, с. 83-88]. Действительно, если обратиться к словарю В.И. Даля, то становится очевидным, что мы имеем дело с обычной этикетной манерой самоуничижения, а не фиксацией монашеского статуса писца, и имеется в виду искаженный термин с греческого «ипокрит», означающий «лицемер, личинник, притворщик, ханжа, облыжный и скрытный самотник, лукавый смиренник» [2, c. 45]. Рукопись не является автографом Олешки и, скорее, является списком более ранней рукописи, возможно им переписанной.

Таким образом, в случае с Олешкой (Александром) мы видим полное подтверждение житийного текста. Писец Олешка действительно имел учеников и выполнял заказы по изготовлению рукописей для Кирилло-Белозерского монастыря еще со времени его первого игумена. Открытым остается вопрос о том, в каком статусе Олешка выполнял эти работы. Житие Мартиниана Белозерского отмечает, что Олешка был дьяком, но этот термин может трактоваться по-разному.

Олешка мог быть дьяконом единственной на тот момент монастырской Успенской церкви, однако против этого есть прямое свидетельство Жития Мартиниана, что Олешка жил за пределами монастырской ограды и, очевидно, не был чернецом Белозерской обители, учитывая весьма строгие общежительные правила при Кирилле. Ни одна из записей на книгах не свидетельствует о монашеском статусе Олешки. Большинство рукописей, переписанных Олешкой, отыскиваются не в монастырской библиотеке, как это произошло с книгами некоторых известных нам монастырских насельников, а в других хранилищах. К примеру, монастырская опись книг, составленная в середине 80-х гг. XV в., фиксирует и книги бывшего настоятеля монастыря Игнатия, и книги знаменитого книжника Ефросина. Но в этой описи учтены только две книги, в которых есть автограф Олешки без какойлибо атрибуции дьяку. Более того, Олешка имел детей, и в одном белозерском акте фигурирует его потомок Степан Александров сын Палкин, составивший завещание землевладельца Насона Захарьина в третьей четверти XV в. [1, с. 103-105; 6, с. 82]. Возможен еще один вариант, что Олешка был монастырским нотарием, то есть дьяком монастырским. Такая категория дьяков действительно фиксируется в актовом материале монастырей в связи с необходимостью уве- 
личения делопроизводительной документации. Как полагает М.С. Черкасова, составление и написание грамот (данных, купчих, разъезжих) к концу XV в. уже выделилось в Кирилловом монастыре в специальную отрасль. До этого к написанию актового материала привлекались сами монахи или представители местного белого духовенства [10, с. 290-310]. Вероятно, таким нотарием мог быть не сам Олешка, а его зять по имени Осташ, женатый на его сестре. Им написано более полутора десятка актов времени Кирилла Белозерского и игумена Христофора. В актах Осташ называет себя всегда дьяком, иногда зятем Павла. Возможно, официально первым монастырским дьяком был Рудель в 70-80 гг. XV в., который так себя и именует $[1$, с. 158,162 , $176,180]$. Однако при весьма удовлетворительной сохранности монастырского архива нам не известно ни одного акта, переписанного Олешкой Павловым, что делает крайне маловероятной возможность того, что Олешка был монастырским дьяком. Олешка мог быть дьяком в услужении у князей, владевших Белозерской землей, Андрея Дмитриевича Можайского и его сына Михаила Андреевича, но в таком случае он, скорее, должен проживать где-то рядом с княжеской резиденцией, а не около монастыря, и следы его деятельности бы нашли какое-либо отражение в грамотах, выданных от имени князей, чего мы не наблюдаем. Остается, на наш взгляд, самый вероятный вариант - Олешка был дьяком (то есть дьяконом) одной из церквей, располагавшихся поблизости от монастыря. Этим собственно и объясняется то, что именно ему Кирилл как не монаху, но все-таки лицу духовного звания доверял переписку книг и обучение учеников, еще не прошедших обряд пострижения. В Житии Кирилла Белозерского сам Олешка не упомянут напрямую, но есть эпизод с неким Павлом, жившим в окрестностях монастыря, просившим об исцелении впавшего в болезнь человека Иакова. Святой ответил отказом, и тогда другой человек, его родственник, имя которого не названо, но отмечено, что святой его любил и он часто приходил к нему, также обратился с просьбой об исцелении, которую в конце концов преподобный Кирилл удовлетворил [4, с. 122, 124]. Основываясь на совпадении имен, можно выд- винуть осторожную гипотезу, что этим человеком мог быть Олешка Павлов, действительно хорошо знавший преподобного. Информатором этой истории мог быть сам Мартиниан, рассказавший об этом автору Жития Пахомию Логофету при составлении Жития Кирилла Белозерского около 1463 года.

Если Олешка был дьяконом приходской церкви, расположенной недалеко от монастыря, то весьма вероятно, что он служил в том же приходе, что и его отец Павел. По белозерским актам поп Павел хорошо известен, но в большинстве актов назван без привязки к какой-либо церкви. Только в Отводной грамоте, датируемой временем около 1492 г., рядом с упоминанием Федосьина городка перечислена «попова пожня Павлова Спасского» $[1$, с. 240], что указывает на то, что, скорее всего, Павел был священником Спасо-Преображенской церкви Федосьина городка. Федосьин городок располагался примерно в 6-7 километрах от монастыря вверх по течению Шексны, рядом с современными Горицами, и был центром волостной княжеской администрации. Свое название городок получил по имени Федосьи, дочери Ивана Калиты. Владения Павла преимущественно располагались рядом с Шексной. Другой настоятель этой церкви поп Окул также фигурирует в кирилловских актах с конца XIV в. [1, с. 15]. Вероятно, он был предшественником Павла в служении в Спасском храме и был вынужден уступить свое место Павлу по причине вдовства, но монахом он не стал и продолжал жить где-то рядом с церковью. В таком случае логично одновременное упоминание и Павла, и Окула как послухов в данной грамоте на Васильев наволок [1, с. 26], принадлежащий до этого попу Никифору, предшественнику, как полагает М.С. Серебрякова, попа Окула в служении в Спасской церкви [9, c. 16-51]. Павел также являлся владельцем части Окуловской деревни, проданной затем Кириллу Белозерскому [1, с. 31]. Кроме того, поп Павел назван первым среди послухов меновной грамоты Кириллова монастыря с тем же попом Окулом на пожню против Городка (Федосьина) [1, с. 27-28]. Другой актовый материал только подтверждает наши предположения о локализация владений Павла и о месте его проживания. Он продал мо- 
настырю деревню Ивашова Мишина, располагавшуюся от Марьевского болота до Городища, а послухом в этом акте был Роман Ворбозомский [1, с. 21]. Марьевское болото и деревня Городище находились в непосредственной близости от Шексны на правом берегу, Ворбозомское озеро располагалось в нескольких километрах от Шексны на другом берегу от Федосьина городка. Как отмечает А.И. Копанев, эта земля находилась где-то рядом с Шексной [3, с. 93]. Кроме того, некий Павел упомянут в данной Василия Александровича Монастырева как бывший владелец «пожней против св. Никиты за озером» [1, с. 29]. Никитский монастырь находился на правом берегу Шексны примерно напротив Гориц.

В заключение отметим, что, на наш взгляд, очень маловероятно, что Олешка руководил начальной школой для молодых насельников в Кирилло-Белозерском монастыpe, как полагают некоторые исследователи [13, p. 136-171]. Вполне обстоятельный критический разбор этой точки зрения дан в работе Е.Э. Шевченко [5, с. 136-137]. В задачи приходского дьяка едва ли могло входить чтолибо большее, чем обучение новичков монастыря азам грамотности. Тем более что Олешка обладал весьма посредственным по качеству полууставом и явно не был каллиграфом-профессионалом. Необходимо учитывать и то, что ряд рукописей переписывался им не только для Белозерской обители.

Итак, анализ биографии Олешки свидетельствует о том, что в первой половине XV в. Кирилло-Белозерский монастырь вынужден был привлекать для написания книг не только братию, но и местных приходских церковнослужителей. В таком случае едва ли можно говорить о сильной развитости монастырского книгописного центра и можно сделать вывод о том, что никакого скриптория, где существовал постоянный штат писцов, в первой половине XV в. Кирилло-Белозерском монастыре еще не сложилось.

\section{СПИСОК ЛИТЕРАТУРЫ}

1. Акты социально-экономической истории Северо-Восточной Руси конца XIV - начала XVI в. М. : Изд-во АН СССР, 1958. - Т. II. - 727 c.
2. Даль, В. И. Толковый словарь живого великорусского языка / В. И. Даль. -СПб. : Издание книгопродавца-типографа М.О. Вольфа, 1881. - Т. 2 : И-О. $-807 \mathrm{c}$.

3. Копанев, А. И. История землевладения Белозерского края XV-XVI вв. / А. И. Копанев. - М. ; Л. : Изд-во АН СССР, 1951. -255 с.

4. Преподобные Кирилл, Ферапонт и Мартиниан Белозерские / изд. подгот. Г. М. Прохоров, Е. Г. Водолазкин, Е. Э. Шевченко. - СПб. : Глаголь, 1994. $330 \mathrm{c}$.

5. Преподобный Мартиниан, Белозерский чудотворец / подгот. текстов, перевод и исследование Е. Э. Шевченко. - СПб. : Пушкинский Дом, 2014. 412 с. : ил.

6. Романчук, Р. Книжник Александр-Олешка Палкин и общежительно-педагогические реформы в Кирилло-Белозерском монастыре при игумене Трифоне (1430-1440-е гг.): к вопросу о православной монашеской образованности / Р. Романчук // Книжные центры Древней Руси. Кирилло-Белозерский монастырь. - СПб. : Дмитрий Буланин, 2008. - C. 72-93.

7. Рукописные книги собрания М.П. Погодина : каталог. -СПб. : Российская национальная библиотека, 2004. - Вып. 3. - 389 с.

8. Русский феодальный архив / текст подгот. А. И. Плигузов, Г. В. Семенченко, Л. Ф. Кузьмина. М. : [б. и.], 1987. - Вып. 3. -459-695, [3] с.

9. Серебрякова, М. С. О начале Кириллова и Ферапонтова монастырей / М. С. Серебрякова // Кириллов : краеведческий альманах. - Вологда : Легия, 2003. - Вып. 5. - С. 16-51.

10. Черкасова, М. С. Сравнительно-историческое изучение монастырских архивов: источники и проблемы / М. С. Черкасова // Кириллов : краеведческий альманах. - Вологда : Легия, 2001. - Вып. 4. C. $290-310$.

11. Шибаев, М. А. Рукописи Кирилло-Белозерского монастыря XV века. Историко-кодикологическое исследование / М. А. Шибаев. - М. ; СПб. : Альянс-Архео, 2013. -560 c.

12. Щапов, Я. Н. Древнерусские княжеские уставы XI-XV вв. / Я. Н. Щапов. - М. : Наука, 1976. $240 \mathrm{c}$.

13. Romanchuk, R. Byzantine Hermeneutics and Pedagogy in the Russian North. Monks and Masters at the Kirillo-Belozerskii Monastery, 1397-1501 / R. Romanchuk. - Toronto ; Buffalo ; London : University of Toronto Press, 2007. $\mathrm{XV}+425 \mathrm{p}$.

14. Ševčenco, I. Oleško Palkin's Colophon in RNB, Pog. 989. Textological Concerns and Erudition of Late Fifteenth-Century Muscovite Bookman / I. Ševčenco // Paleoslavica. - 2003. - № 11. P. 255-261. 


\section{REFERENCES}

1. Akty sotsialno-ekonomicheskoy istorii Severo-Vostochnoy Rusi kontsa XIV-nachala XVIv. [The Acts of the Socio-Economic History of the NorthEast of Russia at the End of 14th-16th Centuries]. Moscow, AN SSSR Publ., 1958, vol. 2. 727 p.

2. Dal V.I. Tolkovyy slovar zhivogo velikorusskogo yazyka [The Explanatory Dictionary of the Great Living Russian Language]. Saint Petersburg, Izdanie knigoprodavtsa-tipografa M.O. Volfa, 1881, vol. 2.807 p.

3. Kopanev A.I. Istoriya zemlevladeniya Belozerskogo kraya XV-XVI vv. [The History of the Land Tenure in the Belozersky Region of the 15th16th Centuries]. Moscow; Leningrad, AN SSSR Publ., $1951.255 \mathrm{p}$.

4. Prokhorov G.M., Vodolazkin E.G., Shevchenko E.E., ed. Prepodobnye Kirill, Ferapont i Martinian Belozerskie [The Reverends Kirill, Ferapont and Martinian of Belozersk]. Saint Petersburg, Glagol Publ., 1994. 330 p.

5. Shevchenko E.E. Prepodobnyy Martinian, Belozerskiy chudotvorets [The Reverend Martinian, Belozersky Wonderworker]. Saint Petersburg, Pushkinskiy Dom Publ., 2014. 412 p.

6. Romanchuk R. Knizhnik Aleksandr-Oleshka Palkin i obshchezhitelno-pedagogicheskie reformy v Kirillo-Belozerskom monastyre pri igumene Trifone (1430-1440-e gg.): k voprosu o pravoslavnoy monasheskoy obrazovannosti [The Bookman Alexander-Oleshko Palkin and Coenobite-Pedagogical Reform in Kirillo-Belozersky Monastery at Abbot Trifon (1430-1440s): On the Issue of the Orthodox Monastic Education]. Knizhnye tsentry Drevney Rusi. Kirillo-Belozerskiy monastyr [Book Centres of Ancient Russia. Kirillo-Belozersky Monastery]. Saint Petersburg, Dmitriy Bulanin Publ., 2008, pp. 72-93.
7. Rukopisnye knigi sobraniya M. P. Pogodina: Katalog. [The Handwritten Books of the Collection of M. P. Pogodin. The Catalogue]. Saint Petersburg, Rossiyskaya natsionalnaya biblioteka Publ., 2004, iss. $3.389 \mathrm{p}$.

8. Pliguzov A.I., Semenchenko G.V., Kuzmina L.F., eds. Russkiy feodalnyy arkhiv [The Russian Feudal Archive]. Moscow, 1987, iss. 3, pp. 459-695, [3] p.

9. Serebryakova M.S. O nachale Kirillova i Ferapontova monastyrey [About the Beginning of Kirillov and Ferapontov Monasteries]. Kirillov: Kraevedcheskiy almanakh [Kirillov: The Almanac of Local History]. Vologda, Legiya Publ., 2003, iss. 5, pp. 16-51.

10. Cherkasova M.S. Sravnitelno-istoricheskoe izuchenie monastyrskikh arkhivov: istochniki i problemy [The Comparative and Historical Study of the Monastery Archives: Sources and Problems]. Kirillov: Kraevedcheskiy almanakh [Kirillov: TheAlmanac ofLocal History]. Vologda, Legiya Publ., 2001, iss. 4, pp. 290-310.

11. Shibaev M.A. Rukopisi Kirillo-Belozerskogo monastyrya $X V$ veka. Istoriko-kodikologicheskoe issledovanie [The manuscripts of the KirilloBelozersky Monastery of the 15th Century. The Historical and Codicological Study]. Moscow; Saint Petersburg, Alyans-Arkheo Publ., 2013. 560 p.

12. Shchapov Ya.N. Drevnerusskie knyazheskie ustavy $X I-X V v v$. [The Old Russian Princely Charters of the 11th-15th Centuries]. Moscow, Nauka Publ., 1976. 240 p.

13. Romanchuk R. Byzantine Hermeneutics and Pedagogy in the Russian North. Monks and Masters at the Kirillo-Belozerskii Monastery, 1397-1501. Toronto; Buffalo; London, University of Toronto Press Toronto Publ., 2007. XV+425 p.

14. Ševčenco I. Oleško Palkin's Colophon in RNB, Pog. 989. Textological Concerns and Erudition of Late Fifteenth-Century Muscovite Bookman. Paleoslavica, 2003, no. 11, pp. 255-261.

\section{Information About the Author}

Mikhail A. Shibaev, Candidate of Sciences (History), Head of Department of Information and Bibliographic Services at the Division of Manuscripts, National Library of Russia, Sadovaya St., 18, 191069 Saint Petersburg, Russian Federation, michailshibaev@mail.ru.

\section{Информация об авторе}

Михаил Алексеевич Шибаев, кандидат исторических наук, заведующий сектором информационно-библиографического обслуживания отдела рукописей, Российская национальная библиотека, ул. Садовая, 18, 191069 г. Санкт-Петербург, Российская Федерация, michailshibaev@mail.ru. 